\title{
Abiotic modulation of Spartina maritima photobiology in different latitudinal populations
}

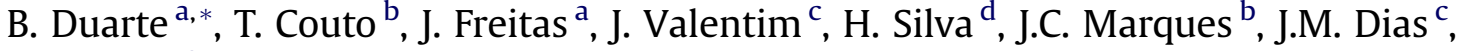 \\ I. Caçador ${ }^{\mathrm{a}}$ \\ ${ }^{a}$ Centre of Oceanography of the Faculty of Sciences of the University of Lisbon (CO), Campo Grande 1749-016 Lisbon, Portugal \\ ${ }^{\mathrm{b}}$ Institute of Marine Research - Marine and Environment Research Centre (IMAR-CMA), c/o Department of Zoology, Faculty of Sciences and Technology, \\ University of Coimbra, 3000 Coimbra, Portugal \\ ${ }^{c}$ Physics Department E' Centre for Environmental and Marine Studies (CESAM), University of Aveiro, Campus de Santiago, $3810-193$ Aveiro, Portugal \\ ${ }^{\mathrm{d}}$ Biology Department E' Centre for Environmental and Marine Studies (CESAM), University of Aveiro, Campus de Santiago, $3810-193$ Aveiro, Portugal
}

\section{A R T I C L E I N F O}

\section{Article history:}

Received 9 October 2012

Accepted 6 February 2013

Available online 4 March 2013

\section{Keywords:}

halophyte

pigments

photosynthetic efficiency

climate

\begin{abstract}
A B S T R A C T
Spartina maritima has a very wide distribution in the northern hemisphere salt marshes crossing a wide variety of climatic environments. Therefore, it is not strange that some differences arise when observing the photosynthetic mechanisms of different populations inhabiting different latitudes. During this study it could be observed that climate is the most important factor controlling the photosynthetic traits of different populations distributed along a climatic gradient, namely the air temperature, humidity and light environment. Also some sediment physicochemical parameters such as $\mathrm{pH}$ and pore water salinity showed important influences driving the photosynthetic mechanisms in S. maritima. Furthermore S. maritima is one of the most abundant halophytes colonizing the Portuguese salt marshes. These facts have greater importance if one considers the large abundance of this halophytic species and how climate change will affect their metabolism and thus the ecosystem services provided by this species to the estuarine system.
\end{abstract}

() 2013 Elsevier Ltd. All rights reserved.
Salt marsh vegetation has a wide geographic distribution due, not only to its long-distance dispersal, but also to the similarities between salt marsh environments around the globe (Adam, 2002). Although these similarities, the key abiotic factors (for e.g. salinity, radiation, air temperature and humidity) affecting these ecosystems have a latitudinal gradient, even at small scales (Pennings et al., 2002). In this context, halophytes with a wide latitudinal distribution are likely to show intra-specific differences between partially and totally isolated populations (Àlvarez et al., 2010). Genetic differentiation among populations within a plant species is well documented, with certain populations being better adapted than others to specific environmental stressors (Keeley, 1979; Silander and Antonovics, 1979; Davies and Singh, 1983; Chung, 1989). This natural genetic variation provides the potential for selection of plant populations exhibiting improved stress tolerance. The Spartina genus is one of the more successful halophytes, being present in a wide range of latitudes across the globe. Some works have already described latitudinal population differentiation of Spartina species (Lessmann et al., 1997; Daehler et al., 1999; Otero et al., 2000; Seliskar et al., 2002; Proffitt et al., 2005; Álvarez

\footnotetext{
* Corresponding author.

E-mail address: baduarte@fc.ul.pt (B. Duarte).
}

et al., 2010). The members of the Spartina genus have C4 photosynthesis using phosphoenolpyruvate carboxylase (PEPC) to concentrate $\mathrm{CO}_{2}$ at higher amounts than it would be observed in a C3 organism (Hatch, 1992; Álvarez et al., 2010). Although this metabolic advantage PEPC is controlled by light-dependent phosphorylation (Echevarría et al., 1990; Vidal et al., 1996), making it very dependent on the surrounding climatic environment. Differences are likely to be found since leaves have high sensitivity to environmental pressures, such as climatic variations, contaminants and grazing (Heide, 2005; Stephenson et al. 2006). In addition, the activation of PEPC by its specific kinase is poor in low light (Bailey et al. 2007) and at low temperatures (Lara et al. 2001), both of which abiotic factors change with latitude.

Spartina maritima (Curtis) Fernald, has a very wide distribution in the northern hemisphere native to the coasts of western and northern Europe and western Africa, with also a disjunct population on the Atlantic coasts of Namibia and South Africa (Marchant and Goodman, 1969). Recently, it has been withdrawing from several salt marshes either due to dieback or to hybridization with other Spartina species, originating polyploid species (Ainouche et al., 2003).

The study described in this paper aimed to identify the differences in the seasonal photobiological traits (PSII photochemistry 
and pigment profiles) between three populations of Spartina maritima from three transitional systems across Portugal latitudinal and climatic gradient, as well as the abiotic factors underlying the differences observed.

\section{Material and methods}

\subsection{Study area and sampling}

Spartina maritima field sampling (Fig. 1) was carried out from June 2010 to May 2011 in Alcochete salt marsh (Tagus estuary), in a large S. maritima extension at Mondego estuary and in Barra salt marsh (Aveiro lagoon). All plant leaves were immediately stored in liquid nitrogen and brought back to the laboratory where they were kept at $-80{ }^{\circ} \mathrm{C}$ until analysis. Simultaneously from April 2010 to February 2011 the aboveground biomass was assessed for each species by clipping out five squares of $0.3 \times 0.3 \mathrm{~m}$. Samples were stored in plastic bags and quickly transported to the laboratory. The aboveground plant biomass collected was washed with Milli-Q water to remove dust and sediment. Plant organs were oven dried at $60{ }^{\circ} \mathrm{C}$ until constant weight. Aboveground biomass was after expressed in a square meter basis $\left(\mathrm{kg} \mathrm{m}^{-2}\right)$. The ratio of belowground to aboveground biomass $(R / S)$ was also determined in order to assess the compartmentalization of the total biomass. Sediment samples $(n=3)$ were collected in pure stands of the selected species, using PVC tubular cores $(9 \mathrm{~cm}$ diameter, $50 \mathrm{~cm}$ long) and transported to the lab in refrigerated bags where they were sliced between 5 and $8 \mathrm{~cm}$ depths.

\subsection{Sediment physical-chemistry}

All the analyses were carried out in sediment samples from 5 to $8 \mathrm{~cm}$ depth, due to the high influence of the root system at this depth (Duarte et al., 2008, 2009). Sediment water content was determined by drying sediment samples at $60{ }^{\circ} \mathrm{C}$ until constant weight. Pore water salinity was measured with a hand refractometer, after pore water extraction by centrifugation at $14,000 \mathrm{~g}$ for $15 \mathrm{~min}$ at $4{ }^{\circ} \mathrm{C}$. Organic matter was determined by the loss on ignition (LOI) method by burning $1 \mathrm{~g}$ of air-dried sediment at $600{ }^{\circ} \mathrm{C}$ for $2 \mathrm{~h}$. Total $\mathrm{N}$ was determined in air-dried and burned sediment samples, using a CHNS/O analyser (Fisons Instruments Model EA 1108).

Sediment $\mathrm{pH}$ was determined by resuspending sediment subsamples in ultra pure water at a ratio of $1: 2.5(\mathrm{w} / \mathrm{v})$.

\subsection{Climatic data mining}

Climatic data collection was withdrawn from the public database from the Portuguese National Institute of Water (www.snirh. pt). For a more robust dataset, the data regarding the last 10 years was used where available and seasonal averages were calculated, in order to characterize climatically the studied periods. Data relative to air temperature, relative humidity, precipitation and radiation were consulted directly in the database, while potential evapotranspiration was calculated using a modified Turc method (Turc, 1961; Douglas et al., 2009):

$$
E T=0.013 \times\left(23.88 \times R_{\mathrm{S}}+50\right) \times\left(\frac{T}{T+15}\right)
$$

where ET is potential evapotranspiration in $\mathrm{mm} /$ day, $R_{\mathrm{S}}$ is solar radiation in $\mathrm{MJ} \mathrm{m} \mathrm{m}^{-2} \mathrm{~d}^{-1}$, and $T$ is average daily air temperature.

\subsection{PAM fluorometry}

Modulated chlorophyll fluorescence measurements were made in attached leaves in the field with a FluoroPen FP100 PAM (Photo System Instruments, Czech Republic). All the measurements in the dark-adapted state were made after darkening of the leaves for at least $30 \mathrm{~min}$. The minimal fluorescence $\left(F_{0}\right)$ in dark-adapted state was measured by the measuring modulated light, which was sufficiently low $\left(<0.1 \mu \mathrm{mol} \mathrm{m}{ }^{-2} \mathrm{~s}^{-1}\right)$ to induce any significant variation

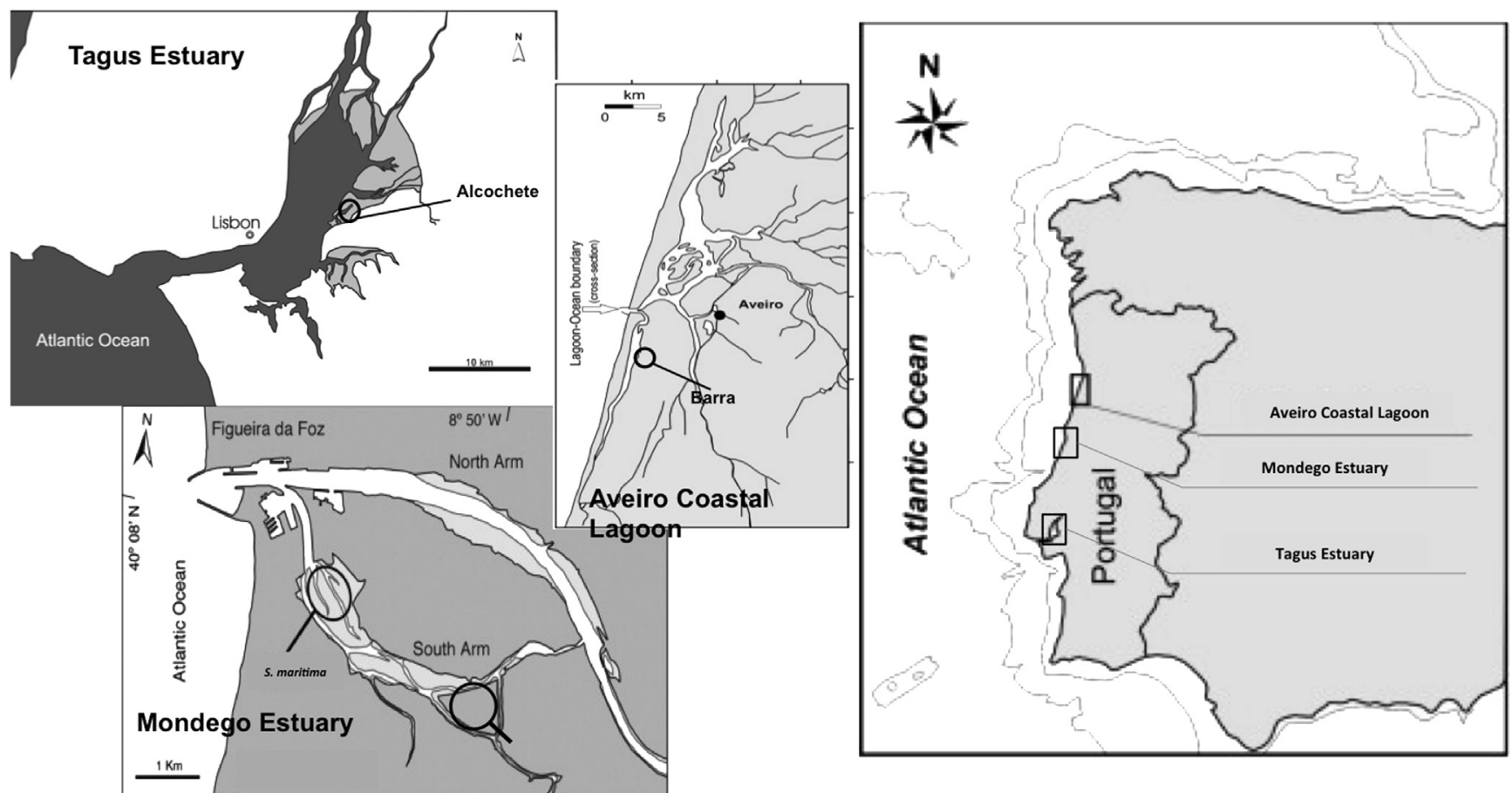

Fig. 1. Field sampling locations in the three considered estuaries. 
in fluorescence. The maximal fluorescence level $\left(F_{\mathrm{M}}\right)$ in darkadapted state was measured by a $0.8 \mathrm{~s}$ saturating pulse at $8000 \mu \mathrm{mol} \mathrm{m} \mathrm{m}^{-2} \mathrm{~s}^{-1}$. The maximum photochemical efficiency was assessed as $\left(F_{\mathrm{M}}-F_{0}\right) / F_{\mathrm{M}}$. The same parameters were also measured in light-adapted leaves, being $F_{0}^{\prime}$ the minimum fluorescence, $F_{M}^{\prime}$ the maximum fluorescence and the operational photochemical efficiency. Rapid light curves $(R L C)$ measurements, in dark-adapted leaves, were attained using the pre-programed LC1 protocol of the FluoroPen, consisting of a sequence of pulses from 0 to $500 \mu \mathrm{mol} \mathrm{m} \mathrm{m}^{-2} \mathrm{~s}^{-1}$. For this protocol the $F_{0}$ and $F_{\mathrm{M}}$ as well as the maximum photochemical efficiency were measured. Each $\Phi_{\text {PSII }}$ measurement was used to calculate the electron transport rate (ETR) through photosystem II using the following equation: $E T R=\Phi_{\text {PSII }} \times P A R \times 0.5$, where PAR is the actinic photosynthetically active radiation generated by the FluoroPen and 0.5 assumes that the photons absorbed are equally partitioned between PSII and PSI (Genty et al., 1989). Without knowledge of the actual amount of light being absorbed, fluorescence measurements can only be used as an approximation for electron transport (Beer et al., 1998a, 1998b; Runcie and Durako, 2004). Rapid light curves (RLC) were generated from the calculated ETRs and the irradiances applied during the rapid light curve steps. Each $R L C$ was fitted to a double exponential decay function in order to quantify the characteristic parameters, $\alpha$ and $E T R_{\max }$ (Platt et al., 1980). The initial slope of the $R L C(\alpha)$ is a measure of the light harvesting efficiency of photosynthesis and the asymptote of the curve, the maximum rate of photosynthesis $\left(E T R_{\max }\right)$, is a measure of the capacity of the photosystems to utilize the absorbed light energy (Marshall et al., $2000)$. The onset of light saturation $\left(E_{\mathrm{k}}\right)$ was calculated as the ratio between $E T R_{\max }$ and $\alpha$.

\subsection{Pigment analysis by Gauss peak spectra (GPS) method}

Leaves for pigment analysis were freeze-dried in the dark during $48 \mathrm{~h}$, after which they were ground in pure acetone with a glass rod. To ensure complete disaggregation of the leaf material, samples with acetone were subjected to a cold ultra-sound bath for $2 \mathrm{~min}$. Extraction occurred at $-20{ }^{\circ} \mathrm{C}$ during $24 \mathrm{~h}$ in the dark to prevent pigment degradation. After extraction, samples were centrifuged at $4000 \mathrm{rpm}$ for $15 \mathrm{~min}$ at $4{ }^{\circ} \mathrm{C}$. For pigment analysis the GPS method was used (Kupper et al., 2007). Samples were scanned in a dual beam spectrophotometer from $350 \mathrm{~nm}$ to $750 \mathrm{~nm}$ at $0.5 \mathrm{~nm}$ steps. The absorbance spectrum was introduced in the GPS fitting library, using SigmaPlot Software.
The employment of this library allowed to identify and quantify Chlorophyll $a$ (MgChl a), Chlorophyll $b$ (MgChl b), Pheophytin $a$ (Pheo a), Antheraxanthin (Anthera), $\beta$-carotene, Lutein, Violoxanthin (Viola) and Zeaxanthin (Zea). In order to better evaluate the light harvesting and photo-protection mechanisms the DeEpoxidation State $(D E S)$ was calculated as:

$D E S=\frac{[\text { Anthera }]+[\text { Zea }]}{[\text { Viola }]+[\text { Anthera }]+[\text { Zea }]}$

\subsection{Statistical analysis}

Due to the lack of normality and homogeneity, the statistical analysis of the data was based in non-parametric tests. Spearman correlations were computed using Statistica 10 Software. In order to understand the interaction and the effect of the abiotic factor (sediment physico-chemistry and climate) a Principal Component Analysis (PCA) and a Similarity Percentage test (SIMPER) were performed using Primer 6 software (Clarke and Gorley, 2006).

\section{Results}

\subsection{Climatic environment}

Observing the light environment of the three studied transitional systems (Table 1 ) it is possible to observe a decrease in both the maximum radiation and the daily average radiation towards higher latitudes. Concomitantly, the same can be observed for all the variables relative to the air temperature with the exception of the thermal amplitude. For the later, it is possible to assess that in winter all the systems present rather similar thermal amplitudes around the $20{ }^{\circ} \mathrm{C}$, while in the remaining seasons Tagus and Mondego showed high thermal amplitudes around $30^{\circ} \mathrm{C}$ (Table 1 ). In the Aveiro coastal lagoon the difference between the maximum and minimum temperatures is smaller. Gathering the information from the air temperature and radiation it was possible to compute the Potential Evapotranspiration on a seasonal basis (Table 1). The results show that this variable had its highest values during the summer, with a decrease towards winter. Spatially Mondego estuary and Aveiro coastal lagoon exhibited similar values, while the Potential Evapotranspiration for Tagus estuary was rather low, when compared with the previous ones. Once again, similarities were observed between Tagus and Mondego estuaries where the

Table 1

Climatic and environmental data for the three studied estuaries, available from snirh.inag.pt.

\begin{tabular}{|c|c|c|c|c|c|c|c|c|c|c|}
\hline & \multicolumn{2}{|c|}{ Radiation ( $\mu \mathrm{mol}$ photons $\mathrm{m}^{-2} \mathrm{~s}^{-1}$ ) } & \multicolumn{4}{|c|}{ Air temperature $\left({ }^{\circ} \mathrm{C}\right)$} & \multirow{2}{*}{$\begin{array}{l}\begin{array}{l}\text { Air relative } \\
\text { humidity (\%) }\end{array} \\
\text { Average }\end{array}$} & \multicolumn{2}{|c|}{ Precipitation (mm/day) } & \multirow{2}{*}{$\begin{array}{l}\text { Potential } \\
\text { evapotranspiration } \\
\text { Average }\end{array}$} \\
\hline & $\begin{array}{l}\text { Average midday } \\
\text { maximum }\end{array}$ & Average & Max & Min & Average & $\begin{array}{l}\text { Thermal } \\
\text { amplitude }\end{array}$ & & $\begin{array}{l}\text { Average } \\
\text { maximum }\end{array}$ & Average & \\
\hline \multicolumn{11}{|c|}{ Tagus Estuary } \\
\hline Spring & $1007 \pm 158$ & $195 \pm 44$ & 40.9 & -5.1 & $15.2 \pm 2.2$ & $31.3 \pm 4.7$ & $71.1 \pm 3.2$ & $21.8 \pm 3.2$ & $0.09 \pm 0.03$ & $6.7 \pm 0.2$ \\
\hline Summer & $981 \pm 53$ & $247 \pm 19$ & 42.7 & -9.3 & $21.8 \pm 1.1$ & $29.9 \pm 0.9$ & $63.7 \pm 1.9$ & $7.8 \pm 5.6$ & $0.01 \pm 0.01$ & $9.9 \pm 1.1$ \\
\hline Autumn & $908 \pm 262$ & $125 \pm 44$ & 42 & -0.1 & $17.4 \pm 3.9$ & $30.7 \pm 5.6$ & $72.8 \pm 6.1$ & $28.0 \pm 11.2$ & $0.1 \pm 0.05$ & $4.6 \pm 0.4$ \\
\hline Winter & $795 \pm 382$ & $82 \pm 21$ & 35 & -9.1 & $10.6 \pm 0.4$ & $21.1 \pm 4.3$ & $80.3 \pm 1.6$ & $22.4 \pm 8.5$ & $0.1 \pm 0.0$ & $2.3 \pm 0.1$ \\
\hline \multicolumn{11}{|c|}{ Mondego Estuary } \\
\hline Spring & $924 \pm 106$ & $183 \pm 39$ & 34.5 & -3 & $14.1 \pm 2.1$ & $31.5 \pm 2.5$ & $76.3 \pm 1.2$ & $17.9 \pm 4.9$ & $0.08 \pm 0.02$ & $14.1 \pm 0.9$ \\
\hline Summer & $983 \pm 57$ & $229 \pm 12$ & 39.5 & -3.8 & $20.3 \pm 0.6$ & $35.7 \pm 4.0$ & $75.3 \pm 0.6$ & $18.5 \pm 18.2$ & $0.03 \pm 0.01$ & $20.2 \pm 2.3$ \\
\hline Autumn & $710 \pm 134$ & $125 \pm 30$ & 36.7 & -3 & $15.7 \pm 3.7$ & $33.7 \pm 3.4$ & $79.5 \pm 2.4$ & $21.5 \pm 4.3$ & $0.12 \pm 0.06$ & $15.7 \pm 1.4$ \\
\hline Winter & $809 \pm 299$ & $97 \pm 22$ & 23.1 & -3.8 & $9.3 \pm 0.4$ & $19.3 \pm 2.7$ & $83.7 \pm 2.4$ & $18.5 \pm 8.6$ & $0.12 \pm 0.01$ & $10.0 \pm 1.6$ \\
\hline \multicolumn{11}{|c|}{ Aveiro Coastal Lagoon } \\
\hline Spring & $925 \pm 130$ & $173 \pm 43$ & 30.6 & 3.2 & $13.8 \pm 1.4$ & $27.4 \pm 1.2$ & $92.9 \pm 4.4$ & $16.6 \pm 7.0$ & $0.10 \pm 0.03$ & $13.8 \pm 0.9$ \\
\hline Summer & $954 \pm 47$ & $239 \pm 16$ & 31.9 & 10.7 & $17.7 \pm 0.2$ & $21.2 \pm 4.2$ & $99.1 \pm 0.6$ & $22.0 \pm 10.7$ & $0.05 \pm 0.01$ & $17.7 \pm 1.1$ \\
\hline Autumn & $648 \pm 161$ & $118 \pm 52$ & 32.5 & 1.7 & $15.9 \pm 2.4$ & $30.8 \pm 1.6$ & $95.4 \pm 2.3$ & $18.2 \pm 2.9$ & $0.16 \pm 0.07$ & $15.9 \pm 1.3$ \\
\hline Winter & $501 \pm 108$ & $71 \pm 21$ & 21.1 & -1.1 & $10.7 \pm 0.5$ & $20 \pm 1.8$ & $92.8 \pm 1.3$ & $14.4 \pm 1.7$ & $0.15 \pm 0.01$ & $11.4 \pm 0.8$ \\
\hline
\end{tabular}


air relative humidity was around $70-80 \%$, while in Aveiro coastal lagoon the average seasonal relative humidity was always above $90 \%$. Regarding the precipitation data, calculated from a 10 -year time series, it showed very similar values among the three monitored systems (Table 1 ).

\subsection{Sediment physical-chemistry}

Regarding sediment water content (Fig. 2) it is recognized that it increases towards the wet seasons, with the sediments collected at Aveiro coastal lagoon showing the highest percentages of water content, while Tagus estuary salt marsh sediments showed the lowest water contents. As for the sediment organic matter content (Fig. 2), the opposite trend was observed, with Tagus estuary having the highest percentages of organic matter (with maximum values in spring and autumn) followed by the rhizosediments collected at Aveiro coastal lagoon (with maximum values in the summer).
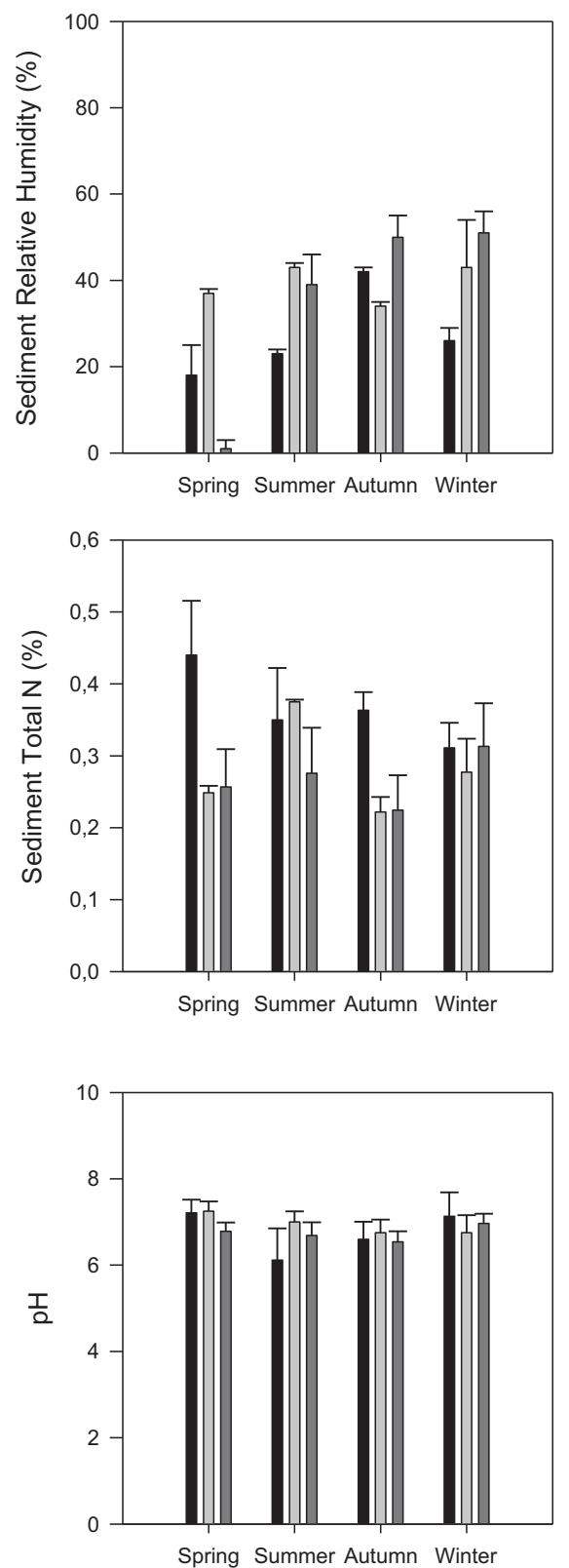

Mondego estuary sediments showed a rather constant value of organic matter content, during the studied period. Pore water salinity (Fig. 2) from Tagus and Mondego estuaries showed a seasonal variation, increasing from spring towards the summer dropping back in the winter season. As for Aveiro coastal lagoon sediments, it was found that although it had some fluctuations, there were no significant variations among the seasons. As for sediment total $\mathrm{N}$ content (Fig. 2), it was observed that, with the exception of Tagus sediments, there is a generalized trend of increasing $\mathrm{N}$ content from spring towards summer, dropping in the autumn and again increasing during winter. Sediment $\mathrm{pH}$ was relatively stable among seasons and marshes (Fig. 2).

\subsection{Biomass production}

For the biomass production it was found that the three analysed ecotypes have different aboveground biomass production seasonal
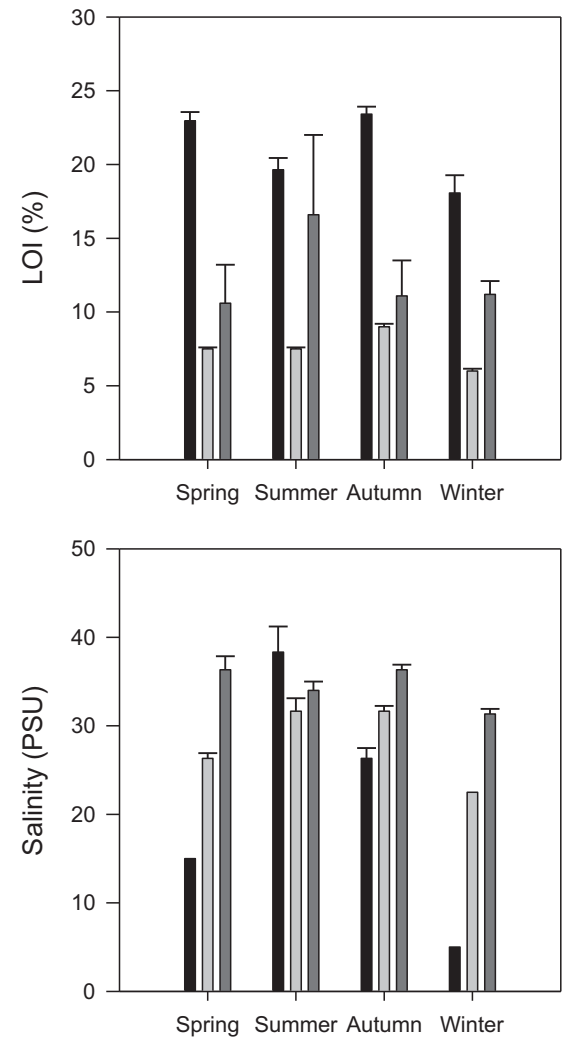

Tagus Estuary

Mondego Estuary

Aveiro Coastal Lagoon

Fig. 2. Spartina maritima sediment physico-chemical characteristics seasonal variation in the three studied systems ( $n=6$, average \pm standard deviation). 
patterns (Fig. 3). While Tagus Spartina maritima showed two peaks of aboveground biomass in spring and autumn, Mondego ecotype showed only one peak of biomass production during the studied period. As for Aveiro ecotype, it did not show any evident seasonal pattern. Regarding root biomass production, only the Mondego ecotype followed the same pattern as for the aboveground biomass. Tagus estuary ecotype showed a belowground biomass peak during summer, while the Aveiro coastal lagoon population of S. maritima showed constantly high belowground biomasses throughout all the year, with the exception of the autumn (Fig. 3). The same can be observed when considering total biomass production, due to the high contribution of the belowground biomass for this value, as reinforced by the $R / S$ ratio.

\subsection{PSII photochemistry}

Considering the operational PSII quantum efficiency (light adapted state), both the Tagus and Mondego ecotypes showed a peak of operational PSII activity during spring, slowly decreasing towards autumn, where it abruptly decreases until its minimum value in winter (Fig. 4). Contrarily, Aveiro ecotype, showed a marked increase from spring towards winter, where the PSII operational efficiency had its maximum. Considering the maximum PSII efficiency (dark adapted state), these patterns are not so evident, although the same seasonal trend can be observed in all three ecotypes (Fig. 4). Regarding the light harvesting efficiency given by $\alpha$ (Fig. 4), it is possible to observe that both Tagus and
Mondego ecotypes showed constant $\alpha$ values from spring to autumn and an absence of light harvesting ability during the winter season. As for the Aveiro ecotype, it was possible to observe an increase of the light harvesting ability from spring towards its maximum in the summer, followed by a small decrease until the winter and spring seasons.

\subsection{Pigment profile}

Both chlorophylls showed similar seasonal patterns within each analysed ecotype (Fig. 5). Tagus estuary Spartina maritima showed a peak of both these pigments at the end of the growing season (autumn), while the Mondego population exhibited its chlorophyll peak during summer. Regarding the Aveiro coastal lagoon ecotype, it showed its chlorophyll maximum concentration during spring. Considering the $\mathrm{Chl}$ a/b ratio (Fig. 6) both the Tagus and Mondego populations exhibited the same trend, ratio values increasing towards summer, followed by a decrease to the levels observed in spring. Aveiro individuals showed an inverse seasonal pattern with lower values during summer, and very high $\mathrm{Chl} a / b$ values in the remaining seasons. Regarding the carotenoids (Fig. 5), $\beta$-carotene, it showed very constant values along all the year in Tagus and Mondego populations, decreasing greatly only during winter. The highest concentrations of $\beta$-carotene were found in the Aveiro ecotype. In this population, $\beta$-carotene showed constant concentrations during the warm seasons, decreasing in the autumn and increasing back during winter. The remaining analysed pigments
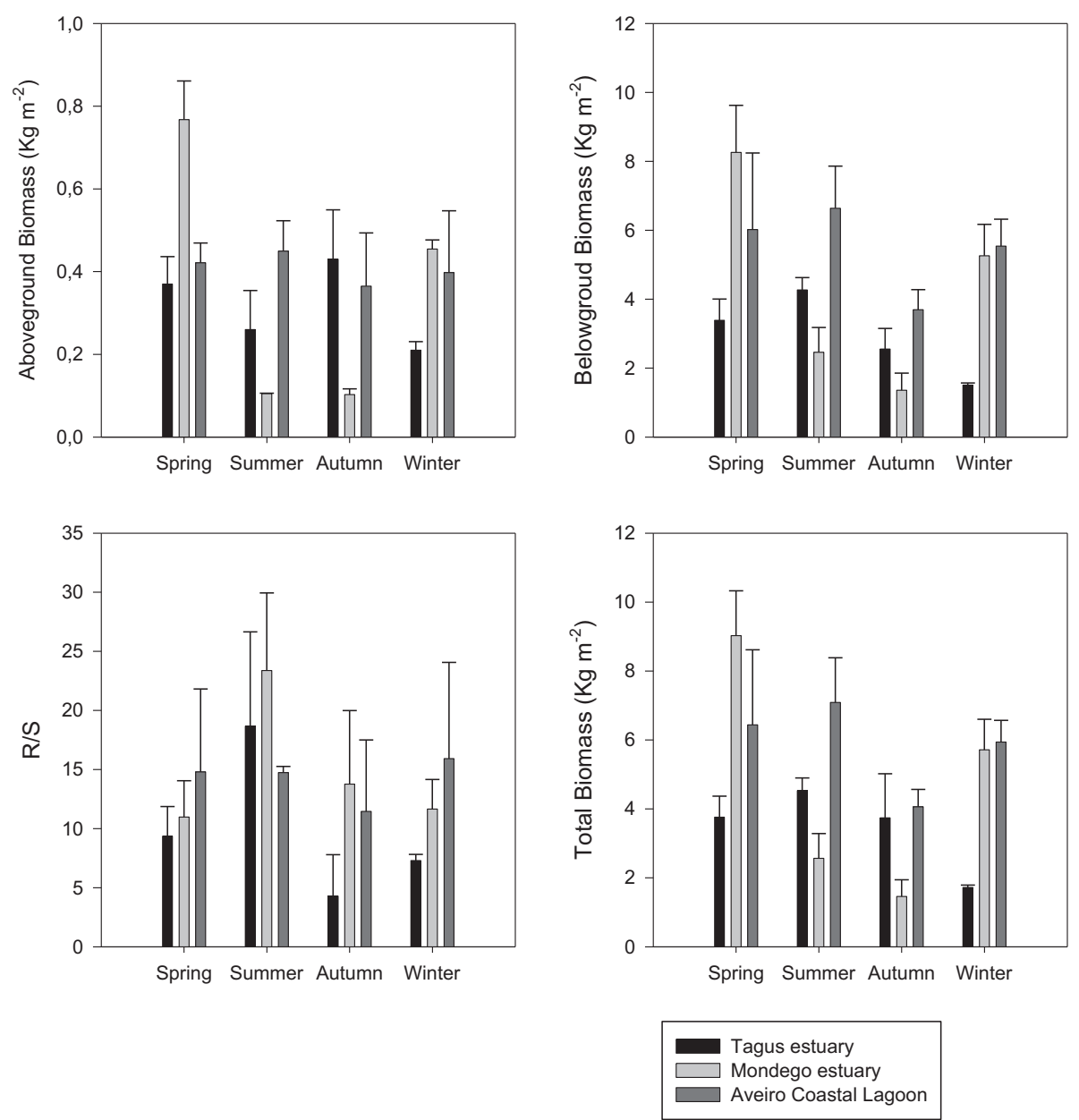

Fig. 3. Spartina maritima biomass production and R/S ratio seasonal variation in the three studied systems ( $n=5$, average \pm standard deviation). 

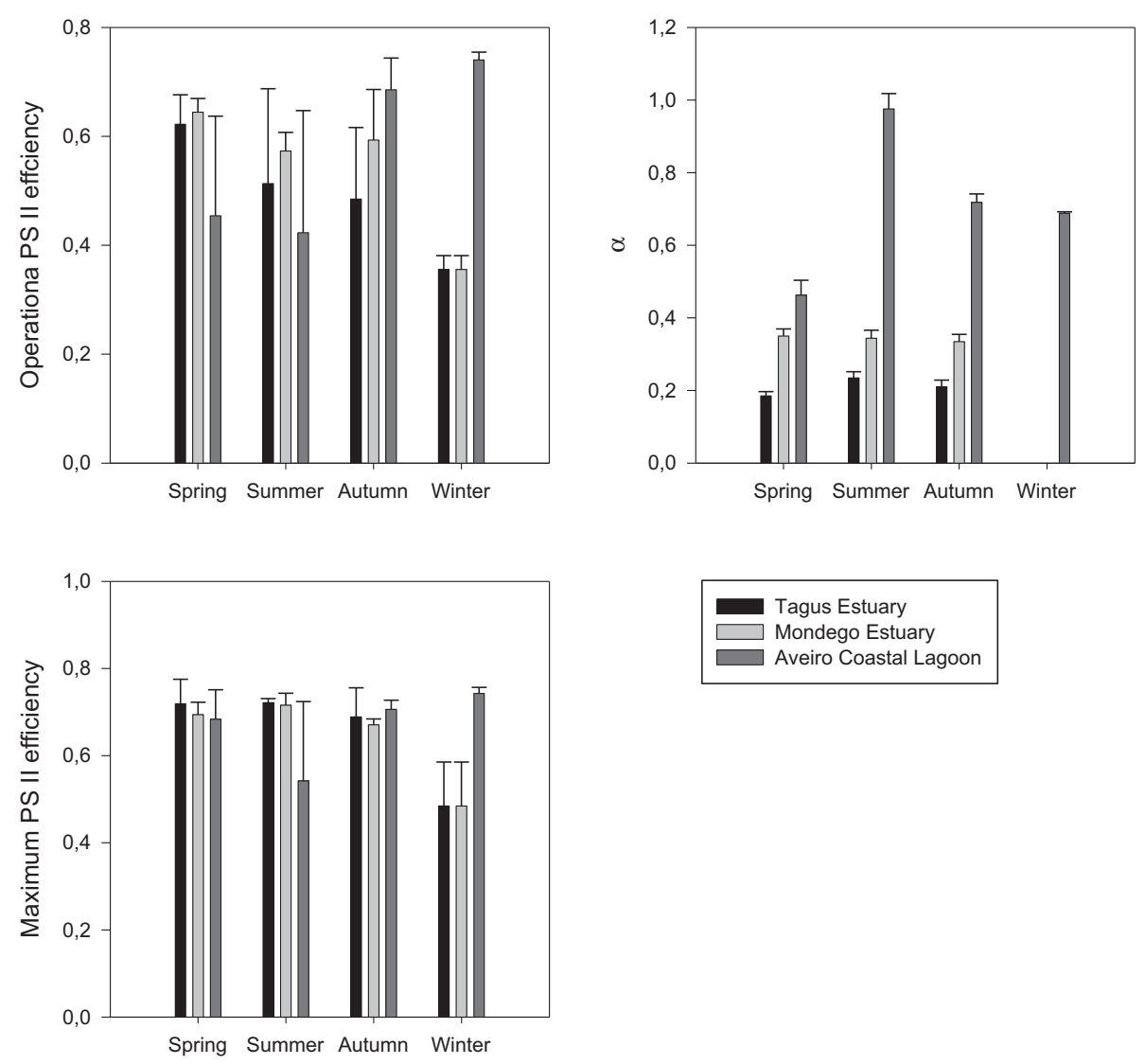

Fig. 4. PSII photochemical parameters seasonal variation in the three studied systems $(n=6$, average \pm standard deviation).

integrate the xanthophyll cycle, thus its seasonal interpretation acquires a more accurate biological sense observing not their concentration, but the DES index, due to its inter-correlated variations (Fig. 6). At this point it was observed that the population from Tagus estuary showed constantly higher values, only decreasing in summer. Mondego and Aveiro ecotypes showed lower values decreasing from spring towards the winter, although Mondego individuals DES index was higher then that verified in the leaves collected at Aveiro coastal lagoon.

\subsection{Abiotic factors versus photosynthetic traits}

Considering the overall correlation coefficients between the photo-biological variables previously described and the climatic and environmental data (Table 2), some important interactions were observed. Biomass production is mostly associated with the thermal environment to which the population is subjected as well as the air relative humidity. For the PSII photochemistry it could be observed that the maximum efficiency and some of the associated parameters are mostly dependent on the sediment nitrogen concentration and humidity (as indirect measure of water availability), but also with the average air temperature and thermal amplitude (Table 2). On the other hand the relative air humidity appear to have a negative effect on the photochemical parameters. If considering only the operational PSII efficiency and associated parameters, there is a strong positive correlation with the sediment pore water salinity, while the average precipitation seems to have the opposite effect on these parameters. Again, and if considering the light harvesting efficiency $(\alpha)$, the pore water salinity, air relative humidity and minimum temperature are the parameters that more influence. As for the pigment profile, both $\mathrm{Chl} \mathrm{a}$ and $\mathrm{b}$ are similarly correlated with the potential evapotranspiration but negatively with the average precipitation. Pore water salinity and radiation also correlated positively with $\mathrm{Chl}$ a concentration in leaves. As for $\mathrm{Chl} b$, the average radiation at midday appear as another environmental factor influencing positively this pigment concentration. On the other hand air relative humidity was negatively correlated to $\mathrm{Chl} \mathrm{b}$ (Table 2 ). Considering the DES correlation with the abiotic factors was found that the potential evapotranspiration, radiation at midday, max air temperature and sediment $\mathrm{N}$ pool showed highly-positive correlations with this index (Table 2). Pore water salinity, sediment relative water content, air relative humidity, minimum temperature and average precipitation correlated negatively with the DES index. As for the $\mathrm{Chl} \mathrm{a} / \mathrm{b}$ ratio, it seems to be negatively influenced by the maximum air temperature, thermal amplitude and average monthly precipitation, but also by the sediment $\mathrm{pH}$. On the other hand, pore water salinity along with air relative humidity and minimum monthly temperature was positively correlated.

Crossing the PCA (Figs. 7 and 8) results with the SIMPER analysis, showed an evident separation of the samples collected in Aveiro coastal lagoon, highly associated to their photosynthetic efficiency parameters but also with the sediment pore water salinity. SIMPER analysis showed that Aveiro samples similarity is mostly due to the importance that the climatic variables have upon these samples photo-biological characteristics (average $d^{2}=0$ ). Another smaller but also evident group, is formed by the winter samples collected at both Tagus and Mondego estuaries. The formation of this group is mostly associated to the sediment average $\mathrm{pH}$ and mean monthly precipitation, but also photo-biologically by the antheraxanthin concentration and high DES index. It was also possible to see that concomitantly to what was described above, 

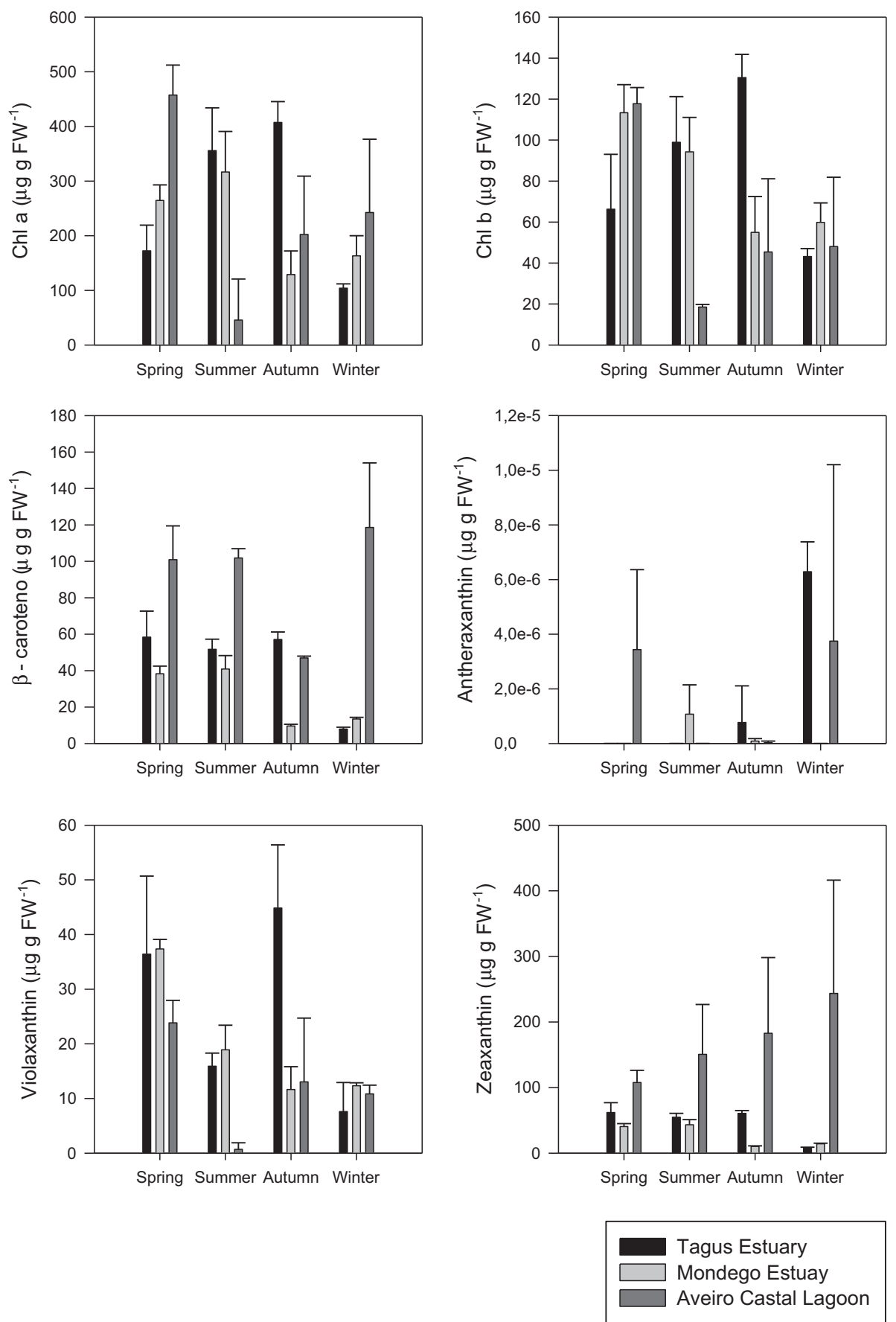

Fig. 5. Leaf chlorophyll and carotenoid concentrations seasonal variation in the three studied systems ( $n=6$, average \pm standard deviation).

this group is also influenced negatively by the lack of PSII light harvesting efficiencies and low associated parameters. The similarity analysis showed that this group was separated from the remaining Tagus and Mondego samples (average $d^{2}=98$ ) due to the influence of the potential evapotranspiration, average air temperature and radiation on the photosynthetic efficiencies, affecting particularly the light adapted maximum and variable fluorescences. Finally, a third group can be evidenced gathering all samples from both Tagus and Mondego estuaries from spring to autumn, mostly influenced by air thermal characteristics, maximum average midday radiation, but also by the sediment $\mathrm{N}$ concentration. On the other hand it is also observed that these samples share similar characteristics in chlorophylls and some carotenoids ( $\beta$-carotene and violaxanthin) concentrations. These last parameters showed the highest contribution to the high similarity observed in this group (average $d^{2}=41.6$ ).

\section{Discussion}

Observing the climatic data from the latitudinal gradient going from Tagus estuary to Aveiro coastal lagoon, there can be evidenced two distinct environments, more markedly in terms of air temperature. There is an evident relationship between biomass production and air temperature, as previously described (Giurgevich and Dunn, 1979; Drake, 1989; Nobel, 1991), as consequence of a C4-photosynthetic mechanism. Although it could be expected that 

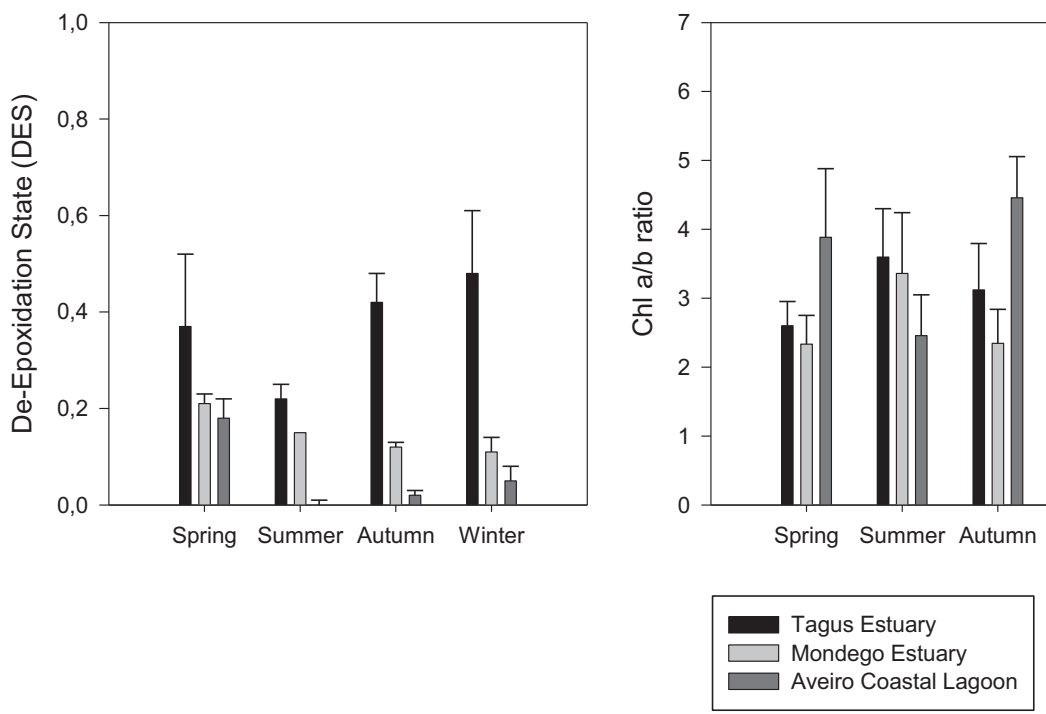

Fig. 6. De-epoxidation state (DES) and $\mathrm{Chl} \mathrm{a/b}$ ration seasonal pattern in the three studied systems ( $n=6$, average \pm standard deviation).

salinity could be a driving function for plant biomass production, it did not appear directly related to this parameter, as seen before for Spartina alterniflora (Cunha et al., 2005). Furthermore, although pore water salinity did not show any relationship with root biomass, this could be masked by precipitation, since this showed an evident correlation with root biomass. Both these influences are more evident if the PSII light-harvesting mechanism itself is analyzed. At this level there is an evident interaction between pore water salinity, precipitation and air humidity with the PSII efficiencies of Spartina maritima. From the data it is evident that salinity, at least under the observed range of salinities, affects positively PSII photochemistry. Belonging to a genus of obligatory halophytes (Koyro and Huchzermeyer, 2004), an increase of precipitation accompanied by a normal increase in air relative humidity would lead to a normal decrease in pore water salinity by dilution, thus affecting the halophytic PSII efficiencies of S. maritima (Mateos-Naranjo et al., 2010). Temperature can both act directly increasing the photosynthetic mechanism (and thus PSII efficiency) at least at temperatures bellow $35{ }^{\circ} \mathrm{C}$ (Cunha et al., 2005) or by increasing pore water salinity due to evaporation, again favoring
PSII photochemistry (Mateos-Naranjo et al., 2010). Furthermore, data points to an increase in the light harvesting capacity with the increase of the minimum air temperature, reinforcing once again the important role of the thermal environment (Gray and Mogg, 2001). Sediment N concentration appeared as another evident factor affecting $S$. maritima PSII efficiencies, in particular the darkadapted state corresponding to the maximum activity achievable. This is in accordance with previous studies that found similar data for other species from the genus Spartina (Madrid et al., 2012). In this study it was found that an increase in sediment $\mathrm{N}$ allowed S. maritima to incorporate higher amounts of $\mathrm{N}$ in its leaves, which correlated with high PSII maximum quantum yields. An elevated value of this parameter is indicative of an efficient and healthy photosynthetic PSII reaction center (Bilger et al., 1995; Maxwell and Johnson, 2000; Quigg et al., 2008). Similar studies (Mendelssohn and Postek, 1982; Pennings et al., 2002), suggested that S. alterniflora could absorb nitrogen as it becomes available in sediments under a wide range of environmental conditions. Another important fact that modulates PSII quantum efficiencies is obviously the light environment. When under light stress

Table 2

Spearman correlation coefficients between the environmental and biological data $\left({ }^{*} p<0.05\right)$.

\begin{tabular}{|c|c|c|c|c|c|c|c|c|c|c|c|c|c|c|}
\hline & $\mathrm{N}$ & $\mathrm{pH}$ & Sal & $\begin{array}{l}\text { Water } \\
\text { content }\end{array}$ & ET & Radiation & $\begin{array}{l}\text { Average } \\
\text { midday rad }\end{array}$ & $\%$ Hum & $\begin{array}{l}\text { Average } \\
\text { temp }\end{array}$ & Min temp & Max temp & $\begin{array}{l}\text { Thermal } \\
\text { amplitude }\end{array}$ & $\begin{array}{l}\text { Max } \\
\text { precipitation }\end{array}$ & $\begin{array}{l}\text { Average } \\
\text { precipitation }\end{array}$ \\
\hline Aereal Biomass & -0.05 & 0.16 & -0.12 & 0.14 & -0.05 & 0.01 & 0.05 & 0.15 & -0.23 & $0.33^{*}$ & -0.31 & -0.25 & -0.11 & 0.02 \\
\hline Root Biomass & -0.26 & 0.01 & 0.29 & 0.12 & 0.11 & 0.19 & 0.11 & $0.34^{*}$ & -0.13 & $0.36^{*}$ & $-0.52^{*}$ & $-0.34^{*}$ & $-0.52^{*}$ & -0.14 \\
\hline$F_{0}$ & 0.27 & -0.03 & 0.20 & 0.20 & 0.27 & 0.25 & 0.03 & $-0.33^{*}$ & $0.47^{*}$ & -0.05 & 0.32 & $0.34^{*}$ & -0.29 & -0.20 \\
\hline$F_{\mathrm{M}}$ & $0.34^{*}$ & 0.02 & 0.11 & 0.28 & 0.17 & 0.14 & -0.01 & $-0.34^{*}$ & $0.39^{*}$ & -0.04 & 0.30 & $0.38^{*}$ & -0.25 & -0.09 \\
\hline$F_{\mathrm{V}}$ & $0.38^{*}$ & 0.04 & 0.06 & 0.29 & 0.12 & 0.08 & -0.03 & $-0.37^{*}$ & $0.34^{*}$ & -0.09 & 0.31 & $0.38^{*}$ & -0.26 & -0.05 \\
\hline$Q Y$ & $0.43^{*}$ & 0.18 & -0.06 & $0.34^{*}$ & 0.06 & 0.01 & -0.01 & -0.33 & 0.24 & -0.09 & 0.26 & $0.47^{*}$ & -0.19 & 0.05 \\
\hline$F_{0}^{\prime}$ & -0.04 & -0.06 & 0.26 & 0.09 & 0.09 & 0.11 & -0.05 & -0.07 & 0.19 & 0.08 & 0.05 & 0.23 & $-0.34^{*}$ & 0.06 \\
\hline$F_{\mathrm{M}}^{\prime}$ & -0.09 & -0.01 & $0.41^{*}$ & 0.13 & 0.07 & 0.09 & -0.12 & 0.03 & 0.18 & 0.17 & -0.05 & 0.24 & $-0.52^{*}$ & 0.13 \\
\hline$F_{\mathrm{V}}^{\prime \prime}$ & -0.06 & 0.01 & $0.44^{*}$ & 0.11 & 0.08 & 0.10 & -0.10 & 0.04 & 0.17 & 0.17 & -0.07 & 0.22 & $-0.58^{*}$ & 0.12 \\
\hline$Q Y^{\prime}$ & -0.05 & -0.04 & $0.57^{*}$ & 0.14 & 0.05 & 0.06 & -0.15 & 0.17 & 0.16 & 0.27 & -0.17 & 0.08 & $-0.66^{*}$ & 0.15 \\
\hline$\alpha$ & -0.16 & -0.29 & $0.58^{*}$ & 0.22 & 0.04 & 0.10 & -0.10 & $0.51^{*}$ & 0.28 & $0.7^{*}$ & -0.26 & -0.11 & -0.11 & 0.22 \\
\hline MgChl a & 0.09 & -0.11 & $0.41^{*}$ & -0.05 & $0.38^{*}$ & $0.35^{*}$ & 0.33 & -0.23 & 0.33 & 0.22 & 0.15 & 0.07 & -0.31 & $-0.35^{*}$ \\
\hline MgChl b & 0.07 & 0.02 & 0.15 & -0.13 & $0.37^{*}$ & 0.33 & $0.34^{*}$ & $-0.42^{*}$ & 0.23 & 0.06 & 0.29 & 0.24 & -0.15 & $-0.38^{*}$ \\
\hline Antheraxanthin & 0.16 & 0.04 & 0.05 & -0.05 & -0.06 & -0.12 & 0.01 & 0.07 & -0.07 & 0.10 & -0.06 & 0.02 & -0.03 & 0.09 \\
\hline$\beta$ carotene & 0.22 & -0.13 & $0.41^{*}$ & 0.07 & 0.09 & 0.09 & 0.11 & 0.06 & 0.15 & $0.38^{*}$ & -0.10 & -0.07 & $-0.38^{*}$ & 0.10 \\
\hline Violaxanthin & 0.16 & 0.19 & -0.01 & -0.05 & $0.38^{*}$ & $0.33^{*}$ & $0.38^{*}$ & $-0.43^{*}$ & 0.22 & 0.09 & $0.33^{*}$ & $0.35^{*}$ & -0.02 & $-0.36^{*}$ \\
\hline Zeaxanthin & 0.04 & -0.25 & $0.53^{*}$ & 0.22 & 0.08 & 0.10 & 0.01 & $0.35^{*}$ & 0.24 & $0.58^{*}$ & -0.24 & -0.13 & -0.31 & 0.14 \\
\hline DES & $0.50^{*}$ & 0.14 & $-0.36^{*}$ & $-0.40^{*}$ & $0.34^{*}$ & 0.29 & $0.49^{*}$ & $-0.83^{*}$ & 0.15 & $-0.76^{*}$ & $0.65^{*}$ & 0.24 & 0.07 & $-0.45^{*}$ \\
\hline Chl a/Chl b & -0.03 & $-0.34^{*}$ & 0.69* & 0.31 & 0.04 & 0.06 & -0.09 & $0.50^{*}$ & 0.28 & $0.52^{*}$ & $-0.36^{*}$ & $-0.35^{*}$ & $-0.39^{*}$ & 0.08 \\
\hline
\end{tabular}




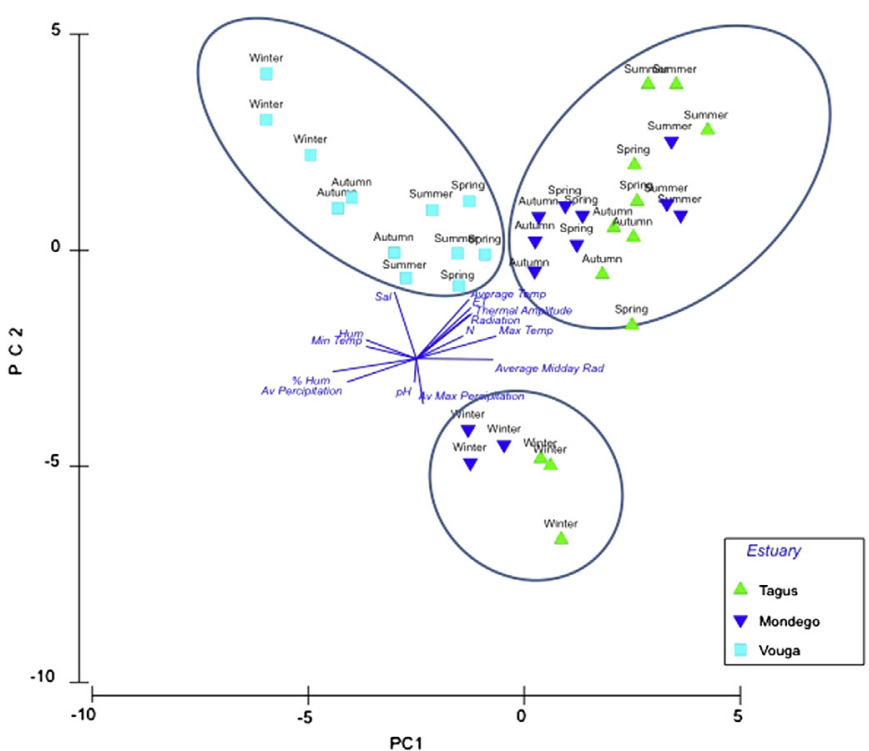

Fig. 7. PCA ordination of all samples according to the climatic and environmental data.

conditions, S. maritima xanthophyll cycle is activated as a protective measure, as confirmed by the increase in the DES index (DemmigAdams and Adams, 1992). In colder seasons (autumn and winter) there is normally higher air humidity, lower temperatures, higher precipitation and consequently lower average midday radiation (mostly due higher cloud presence). Consequently, in these seasons the average light that reaches the photosystems decreases, reducing the probability of PSII light stress during these seasons, as it was verified observing the correlation between the DES index and these climatic variables. Along with light stress, also thermal stresses are responsible for triggering the xanthophyll cycle (Demmig-Adams and Adams, 1992). Similarly, increasing stress can also decrease the $\mathrm{Chl} \mathrm{a} / \mathrm{b}$ ratio, favoring the $\mathrm{Chl} b$ production as stress feedback instead of $\mathrm{Chl}$ a, the principal light harvesting pigment (Demmig-Adams and Adams, 1992). Although these physiological traits are in the basis of the differences observed between populations, after considering also the environmental

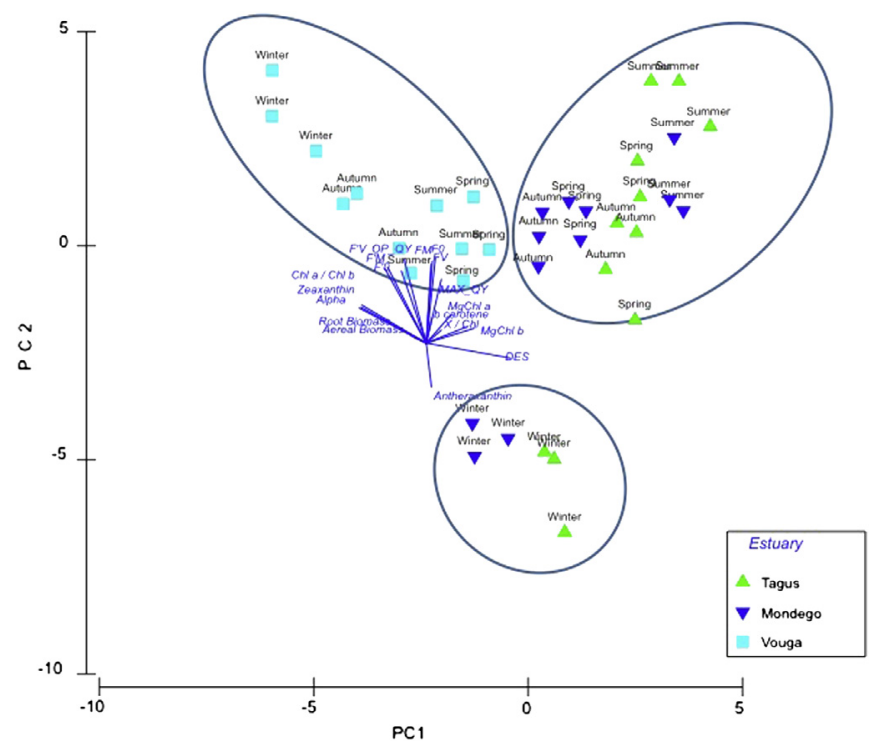

Fig. 8. PCA ordination of all samples according to the photosynthetic traits data. data these differences acquire a new meaning describing the PSII efficiencies of $S$. maritima at different latitudinal environments. Three distinct groups of individuals are evident not only spatially but also seasonally. Although generally, the climatic variables explain most of the observed variations in S. maritima photobiology, overlooking the different groups assembled by the PCA, they could also explain most of the dissimilarities between samples. One of the more evident differences was the gathering of all Aveiro coastal lagoon samples. The basis of this similarity were the climatic variables, contributing to a large proximity among samples harvested at this transitional system. Considering these climatic variables, the climate at this latitude is more stable than in the central region of Portugal, with lower amplitudes and variations between seasons. Considering the photo-biological traits, namely the light harvesting capacity, which is inversely correlated with respiration (Taiz and Zeiger, 2002), it was found to be rather high and constant during almost all year in the individuals studied in Aveiro coastal lagoon. S. maritima has a C4 photosynthetic mechanism, which among other characteristics is temperature dependent, in particular daytime maximum temperature (Taiz and Zeiger, 2002). Furthermore, the respiratory mechanism is temperature dependent. In Aveiro coastal lagoon marshes there are no large variations of temperature over the year, neither maximum or in terms of thermal amplitude. Furthermore, the thermal range verified at this latitude is in agreement with the preferential thermal range for C4 species (Taiz and Zeiger, 2002), favoring the photosynthetic ability. The high dependency of this group with the light environment is reinforced by the low DES index and low antheraxanthin concentrations, supporting the elevated light harvesting capacities found in S. maritima from the Aveiro coastal lagoon. At this latitude it was found that the average maximum midday PAR was always lower than in the remaining systems, which along with the low energy dissipation (low DES), support the high efficiency of these individuals for light harvesting at these light intensities, without undergoing photo-inhibitory processes (Demmig-Adams and Adams, 1992). On the other hand, the individuals collected at Tagus and Mondego salt marshes during the winter season, showed high $D E S$, although the light intensity during this season was the lowest. These high DES values are in agreement with recent data from other C4-halophyte from the Mondego estuary, Scirpus maritimus (Duarte et al., 2012). Due to the very high light intensities verified during the spring-summer period and the low light values verified during the winter, this halophyte, suffers from chronic photo-inhibition. The same can be attributed to S. maritima individuals located at Tagus and Mondego estuaries. On the other hand, it was found that the high precipitation observed during this season and consequent decrease in salinity and $\mathrm{pH}$ increase, together with a decrease in the average minimum temperature, are the principal driving factors for the formation of this group of samples in the PCA. This group is mostly constituted by individuals with very low photosystem II efficiencies and light harvesting capacities, as well as high DES index. All these climatic factors during winter lead to a drift of the environmental conditions, away from the optimal for $S$. maritima. The dilution of pore water salinity is adverse to an obligatory halophyte such as S. maritima (Koyro and Huchzermeyer, 2004), having a consequent decrease in the efficiency of the photosystem II (Naidoo et al., 2012). Additionally, the decrease in the average minimum temperature is also an adverse factor for the $\mathrm{C} 4$ photosynthesis, which has its lower optimum at $8-10{ }^{\circ} \mathrm{C}$ (Taiz and Zeiger, 2002). Previous studies (Long, 1983) suggest that there is a reversible reduction in the $\mathrm{CO}_{2}$ assimilation capacity, that along with the lack of an alternative pathway for the utilization of light-generated reducing power, may be on the basis of the chilling-dependent photo-inhibition of most of the C4 species in particular, from the genus Spartina. Some specific climatic 
conditions can be defined for the warmer seasons (spring, summer and autumn first months), in particular an increase in average and maximum temperature and lower humidities with consequent higher evapotranspiration and higher light intensities. These climatic characteristics, allied with higher $\mathrm{N}$ concentrations in the sediments, provided the ideal conditions for chlorophyll production and increase in the light-adapted photochemical processes. As nitrogen is a structural element of chlorophyll and protein molecules, it becomes understandable that its sediment concentration affects the formation of chloroplasts and accumulation of chlorophyll in them (Daughtry et al., 2000; Tucker, 2004). Also the increase in the light intensities and number of light hours per day can also explain the higher amounts of chlorophyll detected during these seasons, as a mechanism for increasing the light harvest potential of the Mondego and Tagus individuals.

\section{Conclusions}

Climate driven events and conditions are well known drivers of plant species distribution. During this work, it became evident that within the same species, the climatic conditions can also have important roles modulating the photo-biological mechanisms. Spartina maritima populations from different latitudes showed differences in both biomass production and photo-biological traits, seasonal patterns and intensities. Furthermore, as S. maritima is one of the more abundant halophytes colonizing the Portuguese salt marshes, these modulatory mechanisms acquire increased importance. Air temperature and humidity as well as light environment proved to be some of the most important drivers of variability in the photo-biological traits among $S$. maritima populations. Considering a global change in the climate, along with the large abundance of this halophytic species, it becomes of major importance understand the key modulators of S. maritima photo-biology, for a better understanding of how climate change will affect their metabolism and thus the ecosystem services provided to the estuarine system.

\section{Acknowledgments}

The authors would like to thank to the " Fundação para a Ciência e Tecnologia (FCT)" for funding the research in the Centre of Oceanography throughout the project PEst-OE/MAR/UI0199/2011 and this specific work throughout the projects ECOSAM (PTDC/ AAC-CLI/104085/2008) and 3M RECITAL (LTER/BIA-BEC/0019/ 2009). B. Duarte investigation was supported by FCT throughout a PhD grant (SFRH/BD/75951/2011).

\section{References}

Adam, P., 2002. Saltmarshes in times of change. Environmental Conservation 29, 39-61.

Ainouche, M., Baumel, A., Salmon, A., Yannic, G., 2003. Hybridization, polyploidy and speciation in Spartina (Poaceae). New Phytologist 161, 165-172.

Alvarez, R., Castillo, J.M., Mateos-Naranjo, E., Gandullo, J., Rubio-Casal, A.E., Moreno, F.J., Figueroa, M.E., 2010. Ecotypic variations in phosphoenolpyruvate carboxylase activity of the cordgrass Spartina densiflora throughout its latitudinal distribution range. Plant Biology 12, 154-160.

Bailey, K., Gray, J., Walker, R., Leegood, R., 2007. Coordinate regulation of phosphoenolpyruvate carboxylase and phosphoenolpyruvate carboxykinase by light and $\mathrm{CO}_{2}$ during $\mathrm{C}_{4}$ photosynthesis. Plant Physiology 144, 479-486.

Beer, S., Ilan, M., Eshel, A., Weil, A., Brickner, I., 1998a. The use of pulse amplitude modulated (PAM) fluorometry for in situ measurements of photosynthesis in two Red Sea Faviid corals. Marine Biology 131, 607-612.

Beer, S., Vilenkin, B., Weil, A., Veste, M., Susel, L., Eshel, A., 1998b. Measuring photosynthesis in seagrasses by pulse amplitude modulated (PAM) fluorometry. Marine Ecology Progress Series 174, 293-300.

Bilger, W., Schreiber, U., Bock, M., 1995. Determination of the quantum efficiency of photosystem II and non-photochemical quenching of chlorophyll fluorescence in the field. Oecologia 102 (4), 425-432.
Chung, C.H., 1989. Ecological engineering of coastlines with Spartina plantations in China. In: Mitsch, W.J., Jorgensen, S.E. (Eds.), Ecological Engineering-an Introduction to Ecotechnology. Wiley, New York.

Clarke, K.R., Gorley, R.N., 2006. PRIMER v6: User Manual/Tutorial. PRIMER-E, Plymouth.

Cunha, S., Asmus, M., Costa, C., 2005. Production dynamics of Spartina alterniflora salt marshes in the estuary of Patos Lagoon (RS, Brazil): a simulation model approach. Brazilian Journal of Aquatic Science and Technology 9, 75-85.

Daehler, C., Anttila, C., Ayres, D., Strong, D., 1999. Evolution of a new ecotype of Spartina alterniflora (Poaceae) in San Francisco Bay, California, USA. American Journal of Botany 86, 543-546.

Daughtry, C., Walthall, C., Kim, M., Brown de Colstoun, E., McMurtrey, J., 2000 Estimating corn leaf chlorophyll concentration from leaf and canopy reflectance. Remote Sensing of Environment 74, 229-239.

Davies, M.S., Singh, A.K., 1983. Population differentiation in Festuca rubra L. and Agrostis stolonifera L. in response to soil waterlogging. New Phytologist 94, 573-583.

Demmig-Adams, B., Adams, W., 1992. Photoprotection and other responses of plants to high light stress. Annual Review of Plant Physiology and Plant Molecular Biology 43, 599-626.

Douglas, E., Jacobs, J., Sumner, D., Ray, R., 2009. A comparison of models for estimating potential evapotranspiration for Florida land cover types. Journal of Hydrology 373, 366-376.

Drake, B.G., 1989. Photosynthesis of salt marsh species. Aquatic Botany 34,167-1180.

Duarte, B., Reboreda, R., Caçador, I., 2008. Seasonal variation of Extracellula Enzymatic Activity (EEA) and its influence on metal speciation in a polluted salt marsh. Chemosphere 73, 1056-1063.

Duarte, B., Raposo, P., Caçador, I., 2009. Spartina maritima (cordgrass) rhizosediment extracellular enzymatic activity and its role on organic matter decomposition and metal speciation processes. Marine Ecology 30, 65-73.

Duarte, B., Couto, T., Marques, J.C., Caçador, I., 2012. Scirpus maritimus leaf pigment profile and photochemistry during senescence: implications on carbon sequestration. Plant Physiology and Biochemistry 57, 238-244.

Eschevarría, C., Vidal, J., Jiao, J., Chollet, R., 1990. Reversible light activation of the phosphoenolpyruvate carboxylase protein-serine kinase in maize leaves. FEBS Letters 275, 25-28.

Genty, B., Briantais, J.-M., Baker, N., 1989. The relationship between the quantum yield of photosynthetic electron transport and quenching of chlorophyll fluorescence. Biochimica et Biophysica Acta 990, 87-92.

Giurgevich, J.R., Dunn, E.L., 1979. Seasonal patterns of $\mathrm{CO}_{2}$ and water vapor exchange of the tall and short height forms of Spartina alterniflora Loisel in a Georgia salt marsh. Oecologia 43, 139-156.

Gray, A., Mogg, R., 2001. Climate impacts on pioneer saltmarsh plants. Climate Research 18, 105-112.

Hatch, M., 1992. C4 photosynthesis: an unlikely process full of surprise. Plant Cell Physiology 33, 333-342.

Heide, O., 2005. Ecotypic variation among European arctic and alpine populations of Oxyda digyna. Arctic, Antarctic and Alpine Research 37, 233-238.

Keeley, J.E., 1979. Population differentiation along a flood frequency gradient: physiological adaptations to flooding in Nyssa sylvatica. Ecological Monographs 49, 89-108.

Koyro, H.-W., Huchzermeyer, B., 2004. Ecophysiological needs of the potential biomass crop Spartina towsendii Grov. Tropical Ecology 45, 123-139.

Kupper, H., Seibert, S., Aravind, P., 2007. A fast, sensitive and inexpensive alternative to analytical pigment HPLC: quantification of chlorophylls and carotenoids in crude extracts by fitting with Gauss-Peak-Spectra. Analytical Chemistry 79, 7611-7627.

Lara, M., Casati, P., Andreo, C., 2001. In vivo phosphorylation of phosphoenolpyruvate carboxylase in Egeria densa, a submersed aquatic species. Plant Cell Physiology 42, 441-445.

Lessmann, J., Mendelssohn, I., Hester, M., McKee, K., 1997. Population variation in growth response to flooding of three marsh grasses. Ecological Engineering 8 , 31-47.

Long, S., 1983. $C_{4}$ photosynthesis at low temperatures. Plant, Cell and the Environment $6,345-363$.

Madrid, E., Armitage, A., Quigg, A., 2012. The response of photosystem II to soil salinity and nutrients in wetland plant species of the Northwestern Gulf of Mexico. Journal of Coastal Research 28, 1197-1207.

Marchant, C., Goodman, P., 1969. Spartina maritima (Curtis) Fernald. Journal of Ecology 57, 287-291.

Marshall, H., Geider, R., Flynn, K., 2000. A mechanistic model of photoinhibition. New Phytologist 145, 347-359.

Mateos-Naranjo, E., Redondo-Gómez, S., Andrades-Moreno, L., Davy, A., 2010. Growth and photosynthetic responses of the cordgrass Spartina maritima to $\mathrm{CO}_{2}$ enrichment and salinity. Chemosphere 81, 725-731.

Maxwell, K., Johnson, G.N., 2000. Chlorophyll fluorescence-a practical guide. Journal of Experimental Botany 51, 659-668.

Mendelssohn, I.A., Postek, M.T., 1982. Elemental analysis of deposits on the roots of Spartina alterniflora Loisel. American Journal of Botany 69 (6), 904-912.

Naidoo, G., Naidoo, Y., Achar, P., 2012. Ecophysiological responses of the salt marsh Spartina maritima to salinity. African Journal of Aquatic Sciences 37, 81-88.

Nobel, P.S., 1991. Physicochemical and Environmental Plant Physiology. Academic Press, California, 635 pp.

Otero, X., Sanchez, J., Macías, F., 2000. Nutrient status in tall and short forms of Spartina maritima in the salt marshes of Ortigueira (NW Iberian 
Peninsula) as related to physicochemical properties of the soils. Wetlands 20, 461-469.

Pennings, S.C., Stanton, L.E., Brewer, J.S., 2002. Nutrient effects of the composition of salt marsh plant communities along the southern Atlantic and Gulf coasts of the United States. Estuaries 25, 1164-1173.

Platt, T., Gallegos, C., Harrison, W., 1980. Photoinhibition of photosynthesis in natural assemblages of marine phytoplankton. Journal of Marine Research 38, 687-701.

Proffitt, C., Chiasson, R., Owens, A., Edwards, K., Travis, S., 2005. Spartina alterniflora genotype influences facilitation and suppression of high marsh species colonizing an early successional salt marsh. Journal of Ecology 93, 404-416.

Quigg, A., Kevekordes, K., Phillips, J.A., 2008. Ecophysiological status of nine species of macroalgae and seagrasses in Moreton Bay, Queensland, Australia. In: Davie, P.J.F., Phillips, J.A. (Eds.), Proceedings of the 13th International Marine Biological Workshop, The Marine Fauna and Flora of Moreton Bay, Queensland (Brisbane, Australia). Memoirs of the Queensland Museum-Nature, vol. 54 pp. 391-403.

Runcie, J., Durako, M., 2004. Among-shoot variability and leaf-specific absorbance characteristics affect diel estimates of in situ electron transport of Posidonia australis. Aquatic Botany 80, 209-220.
Seliskar, D., Gallagher, J., Burdick, D., Mutz, L., 2002. The regulation of ecosystem functions by ecotypic variation in the dominant plant: a Spartina alterniflora salt-marsh case study. Journal of Ecology 90, 1-11.

Silander, J.A., Antonovics, J., 1979. The genetic basis of the ecological amplitude of Spartina patens. I. Morphometric and physiological traits. Evolution 33, 1114-1127.

Stephenson, D., Oliver, L., Burgos, N., Gbur, E., 2006. Identification and characterization of pitted morningglory (Ipomoea lacunose) ecotypes. Weed Science 54, $78-86$.

Taiz, L., Zeiger, E., 2002. Plant Physiology, third ed. Sinauer Associates, Sunderland, Mass.

Tucker, M., 2004. Primary nutrients and plant growth. In: Essential Plant Nutrients, scribd, ed. North Carolina Department of Agriculture.

Turc, L., 1961. Évaluation des Besoins en Eau D'Irrigation, Évapotranspiration Potentielle. Annales Agronomiques 12, 13-49.

Vidal, J., Pierre, J., Echevarría, C., 1996. The regulatory phosphorylation of $\mathrm{C}_{4}$ phosphoenolpyruvate carboxylase, a cardinal event in $\mathrm{C}_{4}$ photosynthesis. In: Dennis, T.S., Hohn, B., King, P.G., Schell, G., Verma, D.P.S. (Eds.), Plant Gene Research. Signal Transduction in Plant Growth and Development. SpringerVerlag, New York, pp. 141-160. 